
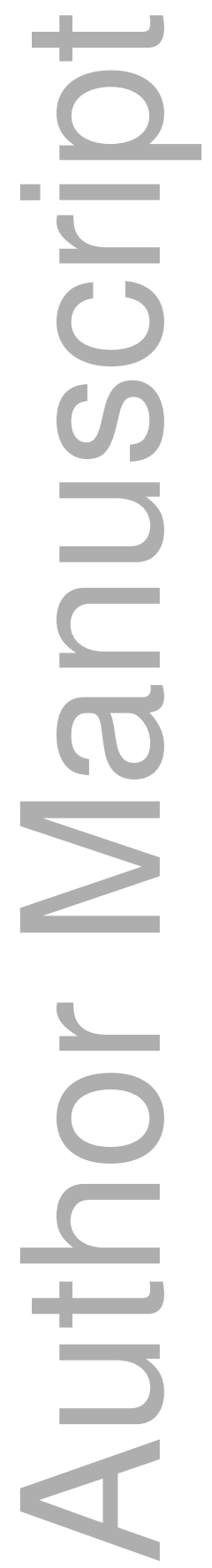

This is the author manuscript accepted for publication and has undergone full peer review but has not been through the copyediting, typesetting, pagination and proofreading process, which may lead to differences between this version and the Version of Record. Please cite this article as doi: 10.1111/jpcu.12706

This article is protected by copyright. All rights reserved 


\section{Genre Worlds and Popular Fiction: The Case of Twenty-First-Century Australian}

\section{Romance}

\section{Lisa Fletcher, University of Tasmania}

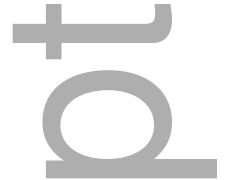

Beth Driscoll, University of Melbourne

Kim Wilkins, University of Queensland

Associate Professor Lisa Fletcher is Deputy Head of the School of Humanities at the University of Tasmania. Her books include Historical Romance Fiction: Heterosexuality and Performativity (2008), Popular Fiction and Spatiality: Reading Genre Settings (2016), and (with Ralph Crane), Island Genres, Genre Islands: Conceptualisation and Representation in Popular Fiction (2017).

Dr Beth Driscoll is Senior Lecturer in Publishing and Communications at the University of Melbourne. Her publications include The New Literary Middlebrow: Tastemakers and Reading in the Twenty-First Century (2014), and chapters in the edited collections By the Book? Contemporary Publishing in Australia (2013) and New Directions in Popular Fiction: Genre, Distribution, Reproduction (2016).

Associate Professor Kim Wilkins is Director of the Writing, Editing and Publishing program at the University of Queensland. Her publications include chapters in the edited collections Digital Gaming Re-imagines the Middle Ages (2014) and New Directions in Popular Fiction: Genre, Distribution, Reproduction (2016). She is the author of more than 25 novels for adults and children, and writes across genres under her own name and under her pseudonym, Kimberley Freeman. Her work has been translated into 25 languages.

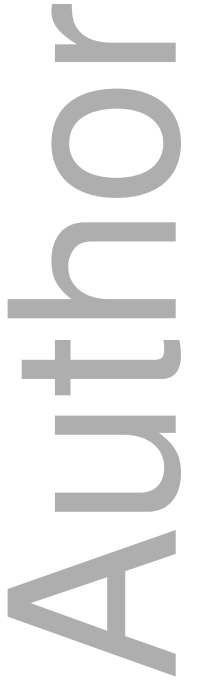

This article is protected by copyright. All rights reserved 
DR. LISA FLETCHER (Orcid ID : 0000-0002-8348-472X)

Article type : Original Manuscript

Corresponding author mail id:- Lisa.Fletcher@utas.edu.au

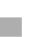

Genre Worlds and Popular Fiction: The Case of Twenty-First-Century Australian Romance

Popular romance fiction is the most prolific and profitable popular genre globally, a robust counter to narratives in the media and academia about the death of the book. Like all genres of fiction, romance has multiple dimensions. Popular romance is a sector of the publishing industry, a social formation, and a body of texts. To date, research has focused overwhelmingly on the third dimension, largely because of the dominance of the conceptual frameworks and analytical techniques of literary critics. To account for the genre's size and growth, its dynamism and diversity, popular romance studies must not privilege a single academic discipline. Instead, the study of romance - and of popular fiction more broadly_ should straddle literary and cultural studies (Butter 201), as well as publishing studies and book history.

This article proposes a new theoretical framework for the study of popular fiction. It introduces the central concept of a "genre world," an adaptation of sociologist Howard S. Becker's definition of an "art world," and models the use of this concept through three interview-based case studies that reveal key characteristics of popular romance in twenty-first century Australia. First, the genre world is both national and international. It is attuned to these different contexts, particularly the permeable boundary between small and large publishing centers. Second, the genre world is highly professionalized, oriented towards the 
accumulation of what we call "genre competence." Popular fiction is a sector of the broader literary field that operates explicitly as a training ground for developing the knowledge and skills required by its members. Third, the romance genre world is built on a dynamic realand-imagined sociality; therefore, people from its past and from its imagined storyworlds are routinely included in accounts of the romance community. The concept of the "genre world" and the methods it invites - reading the texts alongside interviews ${ }^{1}$ with authors and intermediaries and with the support of publishing data — thus yield new insights and a fuller, richer understanding of how genre fiction operates.

\section{Towards a Theory of Genre Worlds}

Howard S. Becker's Art Worlds (1982) offers a sociological study of how art is produced, circulated, and enjoyed. For Becker, art is the result of collective activity, decentralizing the "gifted" individual and reorienting study towards the "radiating network" that surrounds them

(14-15). He defines such networks as "art worlds," whose "cooperative activity, organized via their joint knowledge of conventional means of doing things, produces the kind of art works that art world is noted for" (xxiv). Everything that the artist does not do "must be done by someone else" and wherever the artist relies on someone from this "cast of characters" (xvi) "a cooperative link exists" (25). The artists, as well as the others in the radiating network, embody knowledge about how things are done within the art world via "conventions" which are "known to all or almost all well-socialized members" (42). Becker only accounts obliquely for the world of books and publishing, but his conceptualization is particularly apposite for the study of genre fiction, which is organized by highly networked communities with a strong orientation towards professionalization and industry (conventional behavior) focused on fiction that reproduces and reconfigures well-known tropes (conventional texts). 
Building on Becker's theory, a "genre world" describes the collective activity that goes into the creation and circulation of genre texts, and is particularly focused on the communities, collaborations, and industrial pressures that drive and are driven by the processes of these socio-artistic formations. Becker's work, then, provides a methodology for a better understanding of popular fiction: the analysis of the interrelated parts of the genre world that can be achieved by identifying the "cast of characters"; examining the "cooperative links" between them; and investigating what influence they exert on the final work of art, that is, the genre fiction text: Becker holds that art works "always shows signs of that cooperation" (1). Conceptualizing popular fiction as a genre world leads to a rich understanding of how some of the most widely enjoyed texts in the world come into being and gain new insights into their cultural meaning.

While the "genre worlds" approach is new, it builds on and extends significant prior research on popular fiction. For example, we share Ken Gelder's commitment to studying popular fiction on its own terms, elaborated in his influential monograph, Popular Fiction: The Logics and Practices of a Literary Field, which "speaks up for the reputation of popular fiction" (11). Gelder argues from a Bourdieusian analysis of popular fiction as a "field," rather than a world. "World" is a more central concept in Scott McCracken's Pulp: Reading Popular Fiction, in which "the world, the text, and the reader," are identified as the three main elements of the "total experience of reading popular fiction" (16). McCracken uses "world" to describe the "social context" (2) of texts and genres: popular fiction is "a quintessential product of the modern world" (6) and thus offers readers a vehicle for negotiating and responding to "social conflict" and provides critics with a gauge by which to measure those responses.

The frequent use of the word "world" in recent studies of popular fiction to chart the ideological currents of genres differs from our concept of the "genre world," because we do 
not see the world as something separate to the text and its creation. For example, Jayashree Kamblé offers an ideological account of contemporary romance based in textual analysis, using the term "world" throughout in a sense that chimes with McCracken's world/text/reader triad and advocating analyses that read romance "as a barometer of the ethos of its times" (21). Romance merits scholarly attention, for Kamblé, because it presents conflicting narratives about hegemonic ideologies of class, gender, sexuality, nationality, race, and religion. Gelder, however, is critical of any contention that the "success" of genre novels depends on their engagement with the social contradictions of the modern world, which he rightly points out "would be news indeed to many popular novelists" (Popular Fiction 100). McCracken's and Kamblé's approaches are versions of what Matt Hills terms the "decisionist" approach to popular culture, which holds that the role of scholars is to read texts or cultural practices politically to decide where they fit on a scale from reactionary to progressive ("Media Academics" 39). The decisionist paradigm is most overwhelming in debates about popular romance. Almost without exception, major studies of the genrewhether speaking for or against its aesthetics, pleasures, or effects - begin with the question of the meanings texts produce for (or impose on) their readers.

The idea of a genre world is, in part, an attempt to move beyond decisionist accounts of popular fiction, especially romance, which overemphasize the textual dimensions of genre in their attempts to evaluate the feminist credentials of the genre and its readers. While close reading genre texts is an important part of understanding their cultural meaning, a broader view is enabled by attending to the collaborative networks in which they arise. Like Becker, during the research for the case studies offered below, we "have been more concerned with patterns of cooperation among the people who make the works than with the works themselves or with those conventionally defined as their creators" (Becker xxiii). Robert Cluley provides a pithy summation of Becker's key insight for the study of text-based 
cultures and industries: "Cultural texts allow people to interact and are produced by people interacting" (209). By examining genre texts as part of an interactional world while remaining sensitive to field-wide structures (see Bottero and Crossley 114), we have uncovered some of the key ways in which popular novels function in terms of industry, craft, and community.

The Genre World of Romance in Twenty-First Century Australia

We chose Australian texts for our case studies partly for pragmatic reasons: we are Australian researchers. But it is also important to appreciate the transnationalism of contemporary book cultures and industries. An Australian perspective "reveals both the mobility of books, genres and authors, and the barriers to that mobility" (Carter, "Beyond the Antipodes" 349). Moreover, the descriptor "Australian romance fiction" for a body of texts that are routinely set far from Australian shores, or for a sector of the fiction industry highly dependent on foreign publishers and markets, highlights important questions that are often left unasked when the genre is approached as a textual formation best analyzed hermeneutically.

Popular fiction is a dramatic growth sector in Australian trade publishing. Carter's study of the number of Australian novels published between 2000 and 2013 finds that "fiction publishing — and reading and writing cultures — are in a period of growth, indeed of multiplication" ("General Fiction" 14). The data that Carter has mined from the AustLit electronic database reveals "a growth in genre fiction rather than a decline in literary publishing" (11). The speed and scale of this growth is most marked in romance (Carter "General Fiction" 12-13; see also Driscoll et al.). Our study of the recent publishing history of Australian-authored popular fiction has revealed that the number of romance titles published per year has increased from less than two hundred titles per year in 2000-01 to just under nine hundred in 2015-16. These findings are at odds with many commentaries on 
Australian literature, both within and beyond the academy. The rhetoric of the death of literature in the twenty-first century has become a commonplace in Australian literary journalism (see, for example, Knox; Neill). These grim accounts, however, fail to acknowledge the burgeoning of popular fiction by Australian authors in the national market and globally; for the most part they consider only literary fiction, one small wedge of the publishing pie for Australian authors. This may be less a collective oversight on the part of cultural commentators than it is symptomatic of a powerful prejudice against popular fiction in Australian literary culture, operating nowhere so strongly as against the Australian romance community. On the one hand, popular fiction is "frequently thought of as those books that everyone reads" (Glover and McCracken 1) —and romance is the most "popular" of popular genres (Regis xi; Roach location 158). On the other, romance novels are nearly invisible in the review sections of newspapers and journals, their authors rarely feature on long-running book programs on radio and television, and "literary festivals ignore them more or less completely" (Gelder and Salzman 168).

The relative invisibility of romance from some perspectives is not, however, our starting point for investigation of this genre world. Instead, we begin with the standpoints of those who are active participants in the genre. One of the first tasks when "we have found an art world to study" is to ask, following Becker, "where should our 'observation post' be?" (Cluley 206). In broad terms, this research responds "to the need to be "in the game,"” to use Gelder's phrase by seeking and reporting the perspectives of genre world participants and by acknowledging our own positions as academics who find pleasure in reading romance ("Fields of Popular Fiction" 14).

Romance fiction is more than a commercial phenomenon. Industry data that shows its economic significance and growth and our three case studies provide in-depth, fine-grained knowledge of the texts themselves and the roles of the people involved in their production 
and circulation. The three texts for the case studies were selected to provide a meaningful cross-section of the textual, social, and industrial dimensions of contemporary Australian romance in its international context:

\begin{tabular}{|c|c|c|c|}
\hline Text & Subgenre & Author Profile & Publisher and Format \\
\hline $\begin{array}{l}\text { The Winter Bride } \\
\text { (Book } 2 \text { of } \\
\text { Chance Sisters) } \\
2014\end{array}$ & $\begin{array}{l}\text { historical } \\
\text { romance }\end{array}$ & $\begin{array}{l}\text { Anne Gracie; established author; } \\
\text { seventeenth novel; past president of RWA } \\
\text { (Australia); national \& international award- } \\
\text { winning; widely internationally published }\end{array}$ & $\begin{array}{l}\text { Berkley US (ebook, } \\
\text { pbook); Tantor (audio); } \\
\text { Penguin Australia (ebook, } \\
\text { pbook); Thorndike (large } \\
\text { print) }\end{array}$ \\
\hline $\begin{array}{l}\text { Darkening Skies } \\
\text { (Book } 3 \text { of } \\
\text { Dungirri) } \\
2013\end{array}$ & $\begin{array}{l}\text { romantic } \\
\text { suspense }\end{array}$ & $\begin{array}{l}\text { Bronwyn Parry; mid-career; fourth novel; } \\
\text { national and international award-winning; } \\
\text { some titles internationally published }\end{array}$ & $\begin{array}{l}\text { Hachette Australia (ebook } \\
\text { and pbook) }\end{array}$ \\
\hline $\begin{array}{l}\text { Chaos Born } \\
\text { (Book 1 of } \\
\text { Chronicles of } \\
\text { Applecross) } \\
2012\end{array}$ & $\begin{array}{l}\text { paranormal } \\
\text { romance }\end{array}$ & Rebekah Turner; early career; debut novel & $\begin{array}{l}\text { Harlequin Escape (ebook } \\
\text { only) }\end{array}$ \\
\hline
\end{tabular}

This selection - a Regency by an established and multi-award-winning historical romance novelist, a romantic suspense by a mid-career author, and the first book in a paranormal romance series by a debut author - enables investigation of the breadth and diversity of Australian romance without claiming comprehensiveness. Given the interconnectedness of each author and text with international networks, the findings here also lead to conclusions about how genre worlds work more broadly. In terms of methodology we identified key members of the "cast of characters" for each text and conducted interviews that explored the cooperative links to reveal both the operations and the specific complexion of the popular romance genre world.

\section{National and International Genre Worlds}

Questions of Australian national identity are not the organizing concern of Australianauthored romance fiction, and this is especially the case for those novels that have found success in the United States, the largest marketplace for the genre. However, the twenty-first 
century has seen a growth in interest in the domestic market in Australian rural settings in romance. This growth is most visible in the subgenre of rural romance, or "RuRo" (Driscoll et al. 75), but has also influenced the output of romantic suspense writers such as Bronwyn Parry and Helene Young, and it is relevant to a newly emergent growth in Australian-set historical romance by writers including Tea Cooper and Darry Fraser. Anne Gracie's novel The Winter Bride reveals the more typical model of interaction between the national and international contexts of Australian romance fiction. Gracie's primary publisher is Penguin USA which holds world rights to her work. Her books are written for, edited for, and first published into the American market, where her Regency-set historical romances find a large readership. For Gracie, “Australia is a bonus market” (Gracie, Personal interview). Quantities of mass market American editions of Gracie's books used to be imported by the Penguin Australia office and supplied to bookstores. Then in 2010, Sarah Fairhall, a Penguin Australia editor working in commercial fiction, acquired Australia New Zealand rights for some of Gracie's novels. As Fairhall explains, this involved re-packaging them for the Michael Joseph imprint with new covers and a larger format designed to appeal to bookshops and department stores and to reach a new Australian readership:

Often when we're publishing someone like Anne Gracie here in Australia we're trying to reach new readers, because all of the people here at this [RWA] conference who want The Winter Bride would know that they could get it for $\$ 8$ from Amazon .... So with the $\$ 30$ edition, for example, you're reaching new readers and people who don't necessarily consider themselves part of the romance community, but who actually enjoy that fiction. (Fairhall) In an industrial sense, then, Gracie can be thought of as an American writer whose books are licensed into Australia; her presence/residence in Australia helps catalyze the local marketing of those books. Fairhall's influence is an example of the "signs of cooperation" visible on an 
art work. Her expertise is in publishing, understanding the interplay between national and international factors and connecting them to relevant industrial imperatives such as format, retailers, and pricing. She also shows a knowledge of the conventions of the genre world, predicting the behaviors of readers both inside and outside of it.

Parry's career trajectory illustrates different flows between the Australian and American markets. Parry's career break came in 2007 when she won an American award, the Golden Heart, for an unpublished romantic suspense manuscript. That manuscript was As Darkness Falls, the first of Parry's Dungirri trilogy set in regional Australia. The judges of the Golden Heart are acquiring editors working in romance fiction, and so they occupy the role of taste-shapers in the genre world both in terms of what is valued and what is eventually published. Media coverage of Parry's award led to her being contacted by Bernadette Foley from Hachette Australia, who was expanding their local romance list. Foley brought her own awareness of international trends and national markets to the books. Parry's publisher, then, is the Australian office of a multinational company.

In the words of her friend and mentor Valerie Parv, "Bronwyn definitely has a strong Australian voice." Parry suspects that one of the reasons her books have not been picked up by an American publisher is that her descriptions of Australia are not "the stereotypical outback ... that the American audience is necessarily familiar with.... In As Darkness Falls, the only kangaroo is a dead one." While Parry is passionate about Australia, she is also realistic about developing her career. When asked if she would consider herself an Australian writer, she said,

Yes, I'm an Australian writer, because I'm Australian and obviously these six books have been set in Australia. Those books in particular have been influenced by my Australian experience and my life in the Australian landscape. Career-wise, I'm published by an Australian publisher, so yes, I am 
Australian. But I am working, occasionally, in between other pressures, on a novella that's set in the UK in $1815 \ldots$ where my career trajectory goes from here, I'm not entirely sure. (Parry, Personal interview)

Parry's status as both a member of the Australian literary community (citing her nationality, influence, and the books' setting) and as a member of an international genre world are revealed here. Her acknowledgement that an "American audience" may not be familiar with her descriptions of Australia is evidence that she views her work within a frame that accounts for the expectations of the genre world. Her new project also shows this awareness: the UK in 1815 indicates a Regency setting, and Regency romance is a staple subgenre. Several of Australia's most internationally well-known and successful romance authors write Regency, including Gracie and Stephanie Laurens. In Regency romance, Australian-ness is not a stumbling block for an Australian author seeking an international market. Parry is aware of the textual, industrial, and social conventions of the genre world and of how they might be inflected by her Australian context.

The career of our third case study author, Rebekah Turner, reveals yet another set of interactions between the national and international contexts of the romance genre world. Turner's debut novel, Chaos Born was acquired by Harlequin Escape, an Australian, digitalfirst imprint of a multinational publisher. Chaos Born is not set in Australia, though: it mostly takes place in the fantasy realm of "the Weald." Turner told us that she "wanted to appeal to a wide audience so I thought I would make it neutral.” Turner's aspirations are international, but her sense of being an Australian author came through when she reflected on her professional associations, that is, the "radiating networks" around her and her art work: Inever [identified as an Australian writer] until I got into a writers group and then they were discussing more about genre, being an Australian writer and these are things I'd never really thought of. I thought, being an author you just 
transcend boundaries. And since joining the Queensland Writer's Centre I think, you know, okay I am an Australian writer. But I still like to write books that aren't necessarily in Australia or with that Australian theme or setting. When viewed as a text-based phenomenon, the romance genre world sometimes appears to function transnationally, especially for early career authors. However, as Turner's story shows, close engagement with the processes of professionalization and industrialization can reveal to the writer that she is not an entirely autonomous agent but part of a network of cooperating individuals in which national boundaries are relevant. Books are not straightforwardly global products. Instead, the publishing industry is organized into territories, with ownership of intellectual property rights, marketing, and distribution processes arranged separately for key markets such as North America, the United Kingdom (which sometimes includes Australia and New Zealand), and the rest of the world. Publishing a book means negotiating these transnational barriers and flows.

Turner's publisher, Kate Cuthbert, is highly aware of the significance of Turner's book for the national market. Chaos Born was one of the launch titles for Harlequin Escape. Cuthbert told us that Escape "really wanted to broadcast the diversity of writers that were coming out of Australia." Part of this is about building new markets for romance in Australia: "we knew that there were more opportunities going on and there were more chances for books that were a little bit more niche or weren't at least 'hot' in the Australian market at the time." Yet the fact that the launch titles were chosen to ensure a spread of subgenres, rather than for their Australian content, highlights Cuthbert's role as a genre world curator ("I desperately needed a good paranormal"), and her awareness and focus simultaneously on international markets; Harlequin Escape takes world English rights and publishes its ebooks globally. Like the two earlier case studies, Chaos Born participates in dynamic interactions between the national and international contexts of the romance genre world. 


\section{Professionalizing the Genre World}

Knowledge about the craft of writing and the business of publishing is developed and transmitted between the genre world's members, in one of the clearest examples of cooperation in romance. Our case studies trace the production of works of genre fiction as "collective action," or as "something that a lot of people do together" (Becker qtd. in Plummer 24,25). While genre fiction texts are usually published under the name of one author, there is always a collaborative network that supports the author's capacity to contribute to the genre.

There are several key ways in which authors acquire their writing skills in a genre, or what we call their “genre competence.” Genre competence, a version of Jonathan Culler's "literary competence," describes a member of the genre world's ability to comprehend a text in relation to storytelling conventions that have been learned through reading. Just as we all approach communication armed with a competence formed of "implicit knowledge" and “internalised grammar," so do we also approach literary works with a literary competence. As Culler states, "literary works have structure and meaning because [they] are read in a particular way" (113). To this we would add that literary works are also written, published, and distributed in a particular way. To apply Culler's theory to popular genres, we might usefully imagine the development of genre competence as an experiential model where repeated encounters with genre texts informs future responses to texts. This literary competence equips people to recognize, respond to, and reproduce conventions specific to genres.

A lifetime of reading romances is the most common way of gaining romance writing skills. Gracie speaks of "growing up on Georgette Heyer novels"; Parry explains that she "learned a lot" from the romance books her mother had around the house; while Turner 
actively analyzed similar stories to hers, even making matrices of chapter events to make a "mud map" of how such a novel should play out. (Turner's use of the term "mud map" in our interview is also an apposite reminder of the nuances nationality can add to writers' accounts of their creative process, since this is an Australian term that derives from outback travellers drawing sketch maps on the ground). Genre competence is also acquired and enhanced through structured learning. Turner and her "writing buddy" (a common term within the genre world), Charlotte Nash, remember meeting at the same novel-writing course, and Parry speaks of learning "a lot" from RWA roundtables. The genre world offers many of its own structured learning opportunities, as evidenced by the programming for the Romance Writers of Australia's annual conferences. Gracie recalls presenting a workshop at the 2002 conference "focused on writing techniques for encouraging active reading and for writing a page turner" (qtd in Fletcher). She is running a one-day "boot camp" on the craft of writing romance at the $26^{\text {th }}$ annual conference in 2017 for "aspiring and emerging authors." Structured learning can also come in the form of how-to-write books: Kelly Hunter, who is a "writing friend" of Gracie's, tells of writing retreats where authors bring a recommended craft book: "it goes on the table for that week ... it's like a little library." The genre world of romance appreciates the ways in which craft develops in a network and its participants create and seek opportunities to build new ties and strengthen existing ones.

A genre world is a social entity defined by interaction between its participants. This kind of interaction includes (but is not limited to) discussions and feedback with writing buddies and writing groups, mentors, and editors both pre- and post-publication, discussions and panels between authors and readers, and reader feedback given to the author directly (via social media or "fan mail") and indirectly (via reviewing sites such as Goodreads). Genre worlds also "distinguish between significant and peripheral participants" (Becker 35), and an author is less likely to be influenced by a single reader than to be influenced by an editor or 
peer. Much of the interaction our interviewees described took place between authors, a type of cooperative link about which Becker has little to say. Across the course of our interviews we became interested in the interaction between writing buddies, that is between two writers in a roughly equal relationship, who agree to share and discuss works in progress. These relationships struck us as a crystallizing example of the collaborative work of a genre world. Our interviews suggest that the kind of feedback writing buddies offer each other falls into two categories: development and refinement.

Development encompasses what Hunter calls, "throwing spaghetti at the wall." This refers to discussions authors have about ideas, rather than words on the page. As Gracie's writing buddy, Hunter was involved in early conversations about Gracie's Chance Sisters series (of which The Winter Bride is Book 2). This involved asking open-ended questions"What about, what if you do this?"- to support a process during which possibilities are explored, dissected, and adopted or discarded. Hunter points out that in no way is this process "a collaboration," but says that "it's really freely given," revealing the generosity and sociability that often underpins the cooperative links of this genre world. Our interviews show, too, that writers talk with each other about their works in progress, how to get them written, and how to meet deadlines. Hunter offered us the amusing image of a group of romance writers working out how to keep sex scenes fresh: “we'd done our sums and between us ... maybe three hundred books ... six or seven hundred sex scenes were out there collectively." This highly conventional aspect of genre craft is part of the professional development that gives the genre world of romance its distinctive character.

The other kind of peer assistance with the craft of writing is refinement, which encompasses direct feedback on what has already been written. According to Turner, Nash read multiple versions of Chaos Born and gave her "really good pointers" on how to develop aspects of the romance craft. Nash cites the specific example of the story's love interest, 
Roman the fallen angel, who in the original version of the manuscript pined for a dead wife. Nash advised against this scenario: "very unsexy. ... It doesn't suit him. ... So ... he became ... brooding, no one has touched my heart." Nash told us that she knew this would work better because of "two things, knowledge of genre and also my reaction as a reader." The version of Roman that was eventually published provides an explicit example of the passing of genre competence from one writer to another within a genre world. As with this example, cooperative links frequently change the shape of the finished work.

Becker uses the term "editing" to refer to the work of people who "make (or help the artist to make) the choices which give the work its final shape" (194). It is significant that Becker identifies the "literary editor" as the "prototypical nonartist participant" in the making of artistic choices. The (high) literary art world provides the frame of reference for his contention that "it is not unreasonable to say that it is the art world, rather than the individual artist, which makes the work" (198). Becker's insight is even more pertinent to the genre world of contemporary Australian romance, in which a range of people, including other authors, act as editors to support and develop the genre competence of the author and shape the final text.

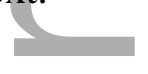

The Cast of Characters: The Real-and-Imagined Romance Genre World The third characteristic of the Australian romance genre world illustrated by our case studies requires a major departure from Becker's sociological theorization of an art world. Becker writes of "flesh-and-blood" and "real people" $(374,379)$, emphasizing the materiality of connections and work. The romance genre world is a living social formation that corresponds readily with Becker's model. It is also, however, an imagined social world where indirect connections - especially with past and living authors and even with some iconic fictional characters - are valued alongside the direct connections with other people or genre "workers" 
that produce romance novels. The phrase "cast of characters," which Becker takes from his mentor Everett Hughes, is clearly metaphorical. Thinking of the people in this world as "characters" helped us to recognize that an account of a world of popular romance that considered only its living "personnel" (as Becker might term them) would be to miss something fundamental about the logics and practices of that world. Becker admits, after all, that the "division of labor does not require that all the people involved in producing the art object be under the same roof, like assembly-line workers, or even that they be alive at the same time" (13). Our interviewed authors were only partially "under the same roof" as the other members of the genre world: Gracie's references to Georgette Heyer, Parry's recollection of learning from romances by Lucilla Andrews and Essie Summers, and Turner's close study of novels by Laurell K. Hamilton and Jim Butcher all show that the genre world includes cooperative links beyond authors' own embodied social interactions. Moreover, even people who have never lived can become influential or contested figures in the genre world: think of Scarlett O'Hara, a fictional creation who casts an enduring shadow over headstrong heroines and historical romances. The way that authors and other intermediaries speak of fictional characters reveals their importance to the genre world, for example Hunter's memory of Gracie's own Merridew sisters, or Gracie's revisiting of the characters of Pride and Prejudice to write the Chance sisters and their heroes (see Fletcher).

Every work of genre fiction reproduces conventional elements and seeks to be original; Gracie describes this as the "tension between predictability and freshness" (qtd in Fletcher). One of the appealing aspects of Becker's theory is that he attaches conventionality to the people who make art rather than to the work that they produce: "the artistic process is so conventionalized" (203). There is a productive tension in genre fiction's dual commitment to originality and to the requirement of conventionality. Becker offers an acknowledgement that the dialogism of familiar and new elements in a genre text can be best appreciated as a 
social encounter, between past and present authors, between authors and characters, the author and her imagined readers, and so on.

Gracie explains that her biggest challenge when writing The Winter Bride was to make Freddy Monkton-Coombes, a girl-shy dandy introduced in the first book in the series, "into a romantic hero." She says that she "wanted someone a bit different from the ... granite-jawed type hero that everyone writes." Gracie's familiarity with and fondness for the character types pioneered by Heyer is evident in her portrayal of Freddy, who even borrows his name from the hero of Heyer's 1953 novel Cotillion. Nevertheless, when writing The Winter Bride, Gracie was also aware that the girl-shy dandy is not a staple figure of twentyfirst century Regency romance. Her friend and fellow Regency writer Mary Jo Putney had called Freddy "quite a silly man," in response to the first book. Gracie "loved" Freddy, but the key was to make "everyone else love him." "Love" is the key word in Gracie's account of how she approached writing Freddy. She recalls that her goal was a convention of the genre worlds: to make Freddy "into a real hero, someone who people ... will love. Romance writing in particular is $100 \%$ about ... readers' engagement, readers loving the books, loving the characters and wanting more of the world. That's the name of the game." This commitment to readers is paralleled by a strong investment in heroes and heroines as imagined participants in the genre world. The Booklist on Gracie's website, for instance, includes the name of the hero and heroine for each title. This is a gesture to the priority readers often grant to characters and evidence that the genre world of romance involves social transactions with both real and imagined people.

It makes sense that the meta-discourse of a genre in which "love" is "the name of the game" privileges characters and their relationships. When the people we interviewed for our case studies speak of characters and connections between characters, they are clearly describing the delight in intertextuality that undergirds what Gelder might term the romance 
genre's "attitude" (Popular Fiction 64). For Parv, "memorable characters" are the first measure of what makes a "great romance." Both Parv and Parry stress "believability" in their discussion of the characters in Darkening Skies. Creating a romance involves working with texts, authors, publishers, and other intermediaries who share an awareness of the high value the genre places on facilitating connections between and with characters. Roman, the character discussed by Turner and her writing buddy Nash, became significant in the publication and marketing of Chaos Born. After it was revised and submitted to Harlequin Escape, Cuthbert singled out the character of Roman as one of the book's unique selling points. As far as brooding paranormal male leads go, the fallen angel was "something that wasn't over - the market hadn't been saturated in that yet, so we put [the proposal to publish] up on that a lot." Cuthbert, like Gracie, emphasized the importance of a compelling hero: "romance readers respond quite viscerally to the kind of hero that they want to read about .... this is the kind of story that's going to be built around [a] man that they're interested in reading [about]." In the examples of Roman and of Freddy Monkton-Coombes, we can see how fiction characters are part of the networks of genre worlds, functioning as imagined “support personnel” (to repurpose one of Becker's preferred terms for nonartist participants) for writers.

\section{Conclusion}

This research reveals new information about how one genre world, that of romance fiction, operates in contemporary Australia. Our interviews, close textual reading, and use of industry data have shown some of the on-the-ground workings that affect how romance texts are created and distributed. The romance genre world as configured in twenty-first century Australia has at least three defining characteristics: a simultaneous national and international orientation; a professionalizing function; and an embrace of historical, living, and fictional 
participants. Moreover, these three characteristics have a common plasticity: the borders of the genre world of Australian romance are not strictly defined or fixed but expand or contract depending on how the world's connections (and disconnections) are activated. These findings underscore the value of romance fiction as an adaptable and dynamic sector of the publishing industry, as well as a source of social connection and creative nourishment for its participants.

Further, this pilot study offers a "proof of concept" that shows how the theoretical framework of the genre world can be followed to reframe and re-energize studies of popular fiction. By seeing genre texts as embedded in genre worlds, we chart routes beyond limited modes of hermeneutic analysis to include sociological and industry perspectives, providing multifaceted accounts of genre fiction. The concept of a "genre world" lays the foundations for further research which acknowledges the particularity and distinctiveness of selected authors and texts at the same time as opening up the operations of genre as an industrial, social, and textual system.

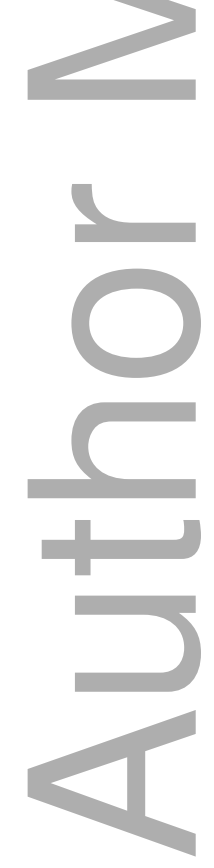




\section{Works Cited}

Becker, Howard S. Art Worlds. 25th Anniversary Edition. U of California P, 2008.

Bottero, Wendy, and Nick Crossley. "Worlds, Fields and Networks: Becker, Bourdieu and the Structures of Social Relations." Cultural Sociology, vol. 5, no. 1, 2011, pp. 99119

Butter, Michael. "Caught Between Cultural and Literary Studies: Popular Fiction's Double Otherness." Journal of Literary Theory, vol. 4, no. 2, 2010, pp. 199-216.

Carter, David. "Beyond the Antipodes: Australian Popular Fiction in Transnational Networks." New Directions in Popular Fiction: Genre, Distribution, Reproduction, edited by Ken Gelder, Palgrave Macmillan, 2016, pp. 349-70.

—_. "General Fiction, Genre Fiction and Literary Fiction Publishing 2000-13." The Return of Print? Contemporary Australian Publishing, edited by Aaron Mannion and Emmett Stinson, Monash UP, 2016, pp. 1-25.

Cluley, Robert. “Art Worlds and Art Worlds: The Methodological Importance of Language Use in Howard S. Becker's Sociology of Art and Cultural Production.” Cultural Sociology, vol. 6, no. 2, 2012, pp. 201-16.

Culler, Jonathan. Structuralist Poetics: Structuralism, Linguistics and The Study of

Literature. Routledge and Kegan Paul, 1975.

Cuthbert, Kate. Personal interview. 1 Nov. 2015.

Driscoll, Beth, et al. "Women, Akubras and Ereaders: Romance Fiction and Australian Publishing." The Return of Print? Contemporary Australian Publishing, edited by Aaron Mannion and Emmett Stinson, Monash UP, 2016, pp. 67-87.

Fairhall, Sarah. Personal interview. 22 Aug. 2015.

Fletcher, Lisa. "Writing the Happy Ever After: An Interview with Anne Gracie.” Journal of Popular Romance, vol. 4, no. 2, 2014, 23 Mar. 2017, 
http://jprstudies.org/2014/10/writing-the-happy-ever-after-an-interview-with-annegracieby-lisa-fletcher. Accessed 17 Apr. 2018.

Gelder, Ken. “The Fields of Popular Fiction.” New Directions in Popular Fiction: Genre, Distribution, Reproduction, edited by Ken Gelder, Palgrave Macmillan, 2016, pp. 119.

Popular Fiction: The Logics and Practices of a Literary Field. Routledge, 2004.

Gelder, Ken, editor. New Directions in Popular Fiction: Genre, Distribution, Reproduction. Palgrave Macmillan, 2016.

Gelder, Ken, and Paul Salzman. After the Celebration: Australian Fiction 1989-2007.

Melbourne UP, 2009.

Glover, David, and Scott McCracken. Introduction. The Cambridge Companion to Popular Fiction, edited by David Glover and Scott McCracken, Cambridge UP, 2012, pp. 114.

Gracie, Anne. Personal interview. 23 Aug. 2015.

The Winter Bride. Penguin, 2014.

Hills, Matt. "Media Academics as Media Audiences: Aesthetic Judgments in Media and Cultural Studies." Fandom: Identities and Communities in a Mediated World, edited by Jonathan Gray et al., New York UP, 2007, pp. 33-47.

Hunter, Kelly. Personal interview. 23 Aug. 2015.

Kamblé, Jayashree. Making Meaning in Popular Romance Fiction: An Epistemology.

Palgrave Macmillan, 2014.

Knox, Malcolm. "The ExFactor: BookScan and the Death of the Australian Novelist." The Monthly, May 2005, pp. 51-55.

Nash, Charlotte. Personal interview. 31 Oct. 2015. 
Neill, Rosemary. "Who is Killing the Great Books of Australia: Lits Out." Australian, 18 Mar. 2006, p. 1.

Mannion, Aaron, and Emmett Stinson, editors. The Return of Print? Contemporary Australian Publishing. Monash UP, 2016.

McCracken, Scott. Pulp: Reading Popular Fiction. Manchester UP, 1998.

Parry, Bronwyn. Darkening Skies. Hachette, 2013.

Personal interview. 17 Oct. 2015.

Parv, Valerie. "Re: Research into Romance Writing.” Received by Beth Driscoll, 18 April 2016.

Plummer, Ken. “Continuity and Change in Howard S. Becker's Work: An Interview with Howard S. Becker.” Sociological Perspectives, vol. 46, no. 1, 2003, pp. 21-39.

Regis, Pamela. A Natural History of the Romance Novel. 2003. U of Pennsylvania P, 2007. Roach, Catherine M. Happily Ever After: The Romance Story in Popular Culture. Kindle edition, Indiana UP, 2016.

Turner, Rebekah, Chaos Born. Escape, 2012.

- Personal interview. 31 Oct. 2015.

\footnotetext{
${ }^{1}$ This study was approved in accordance with the ethical review guidelines and processes of the University of Tasmania and the National Statement on Ethical Conduct in Human Research (UTas Approval Number H0014836), and participants consented to their names being used.
} 


\section{University Library}

\section{- M M I N E R VA A gateway to Melbourne's research publications}

Minerva Access is the Institutional Repository of The University of Melbourne

Author/s:

Fletcher, L;Driscoll, B;Wilkins, K

Title:

Genre Worlds and Popular Fiction: The Case of Twenty-First-Century Australian Romance

Date:

2018-08-01

Citation:

Fletcher, L., Driscoll, B. \& Wilkins, K. (2018). Genre Worlds and Popular Fiction: The Case of Twenty-First-Century Australian Romance. JOURNAL OF POPULAR CULTURE, 51 (4), pp.997-1015. https://doi.org/10.1111/jpcu.12706.

Persistent Link:

http://hdl.handle.net/11343/284256 